\title{
KOMPARYCJA UMÓW WIETNAMSKICH W PRZEKŁADZIE NA JEZZYK POLSKI
}

\author{
Bogdan NOWICKI, mgr \\ Instytut Językoznawstwa, Wydział Neofilologii \\ Uniwersytet im. A. Mickiewicza \\ Al. Niepodległości 4, 61-874 Poznań \\ bognow@amu.edu.pl
}

\begin{abstract}
Abstrakt: Celem niniejszego artykułu jest przybliżenie problemów związanych z wietnamskopolskim przekładem komparycji umów. Problemy translacyjne dotyczące przekładu prawniczego polsko-wietnamskiego i wietnamsko-polskiego w dużej mierze wynikają z uwarunkowanych historycznie różnic w rzeczywistości prawnej, w jakiej zanurzone są teksty sformułowane w tych językach. Komparycja wietnamskiej umowy jest bardziej złożona niż w przypadku paralelnych tekstów polskich. Metody badawcze zastosowane w pracy obejmują: metodę porównania tekstów paralelnych, model pragmatyczny przekładu prawniczego Kierzkowskiej (2002) oraz teorię skoposu Vermeera (2001). Ponadto, przy przekładzie terminologii bezekwiwalentowej lub częściowo bezekwiwalentowej uwzględniono techniki zapewniania ekwiwalentów. Omówiono następujące części komparycji umów wietnamskich: a) inwokację, b) nagłówek i dookreślenie przedmiotu umowy, c) podstawy prawne i preambułę określającą przyczyny zawarcia umowy, d) datę i miejsce zawarcia umowy, e) oznaczenie stron i f) sentencję dotycząca uzgodnień. W ostatniej części pracy wysunięto wnioski translacyjne.
\end{abstract}

Słowa kluczowe: przekład prawniczy, przekład umów, tłumaczenie wietnamsko-polskie, komparycja

\section{HEADING AND RECITALS OF VIETNAMESE CONTRACTS IN TRANSLATON INTO POLISH}

\begin{abstract}
This paper deals with Vietnamese-Polish and Vietnamese-Polish translation of headings and recitals of contracts. Translation problems in this respect result from historicallyconditioned legal system differences. The recitals of Vietnamese contracts are much more complex than their Polish counterparts. The reasearch methods applied have included: the comparison of comparative texts (called by Neubert parallel texts), the pragmatic model of legal translation of Kierzkowska (2002) and skopos theory of Vermeer (2001). Furthermore, the techniques of providing equivalents for non-equivalent or partially equivalent terminology have been applied as well. The component parts of the recitals of Vietnamese contracts have been discussed. Finally, translative conclusions have been drawn.
\end{abstract}

Key words: legal translation, translation of contracts, Wietnamese-Polish translation, recitals

\section{PHẦN MỞ ĐẦU CÁC HỢP ĐỒNG CỦA VIỆT NAM DỊCH RA TIẾNG BA LAN}

Tóm tắt bằng tiếng Việt: Mục đích của bài viết này là làm xích lại gần nhau các vấn đề liên quan đến bản dịch Việt - Ba các phần mở đầu của hợp đồng. Các vấn đề dịch thuật liên quan đến bản dịch pháp luật $\mathrm{Ba}-$ Việt và Việt $-\mathrm{Ba}$, ở một mức độ khá lớn, xuất phát từ sự khác biệt do lịch sử để lại trong thực tế pháp lý mà các văn bản hình thành trong các thứ tiếng. Các phần mở đầu hợp đồng của Việt Nam phức tạp hơn các văn bản có giá trị như nhau với hợp đồng của Ba Lan. Phương pháp nghiên cứu được áp dụng trong bài viết gồm: phương pháp so sánh các văn bản có hiệu lực như nhau , mô hình thực dụng của bản dịch pháp luật của Kierzkowska (2002) và lý 
Bogdan Nowicki, Komparycja umów wietnamskich w przekładzie na język polski

thuyết scopos của Vermeer (2001). Ngoài ra bên cạnh bản dịch các thuật ngữ không tương đương hoặc tương đương một phần đã có chú ý đến các kỹ thuật bảo đảm sự tương đương. Những phần mở đầu các hợp đồng của Việt Nam được nói đến lần lượt là: a) quốc hiệu, b) đầu đề và xác định rõ thêm đối tượng của hợp đồng, $\mathrm{c}$ ) nền tảng pháp lý và phần mở đầu xác định lý do ký kết hợp đồng, d) ngày tháng và địa điểm ký kết hợp đồng, e) ghi tên của hai bên f) thỏa thuận của hai bên. Trong phần cuối của bài viết có những kết luận về mặt dịch thuật được rút ra.

\section{Słowa kluczowe:}

\section{Wstęp}

Celem niniejszego artykułu jest przybliżenie problemów związanych z wietnamskopolskim przekładem komparycji umów. Problemy translacyjne dotyczące przekładu prawniczego polsko-wietnamskiego i wietnamsko-polskiego w dużej mierze wynikają z uwarunkowanych historycznie różnic w rzeczywistości prawnej, w jakiej zanurzone są teksty sformułowane $w$ tych językach. Jest to trudność niekiedy niemal nie do pokonania, zwłaszcza dla adeptów przekładu.

Jako materiał wyjściowy dla języka wietnamskiego posłużył korpus umów wietnamskich zebranych przez autora. Obejmował on 29 autentycznych umów wietnamskich oraz 110 umów cywilno-prawnych zawartych w poradniku „,110 mẫu hợp đồng kinh tế thông dụng và mới nhất” wydanego przez Nhà xuất bản Hồng Dức 2013. Zebrane umowy sporządzone są zgodnie z Kodeksem Cywilnym oraz z Kodeksem Handlowym, które weszły w życie 1 stycznia 2006 r. W celu dokonania porównania tekstów polskich i wietnamskich wykorzystano także korpus 23 autentycznych umów polskich sporządzonych zgodnie z przepisami polskiego Kodeksu Cywilnego z 1964 r. z późniejszymi zmianami.

Problemy tłumaczeniowe dotyczące przekładu prawniczego $\mathrm{w}$ ramach pary języków polskiego i wietnamskiego są związane z różnicami w systemach prawnych. W pierwszej części artykułu opisano krótko różnice w rzeczywistości prawnej języków polskiego i wietnamskiego. Dodatkową trudność stanowi brak słowników bilingwalnych zarówno ogólnych jak i specjalistycznych dla tej pary języków. Jedyną pomocą są zbiory tekstów paralelnych. W drugiej części przywołano podstawy teoretyczne z zakresu translatologii, na których autor oparł swoją analizę komparycji umów wietnamskich. W trzeciej części z kolei przedstawiono strukturę komparycji i problemy translacyjne, mogące się pojawić w pracy tłumacza. Autor proponuje też sposób tłumaczenia na język polski analizowanych komponentów wietnamskich umów.

\section{Różnice w rzeczywistości prawnej Wietnamu i Polski w zarysie}

W Wietnamie obowiązuje system socjalistyczny. Wietnam jest państwem jednopartyjnym, w którym partią rządzącą na mocy zapisu w konstytucji jest Komunistyczna Partia Wietnamu. Najwyższym organem władzy jest jednoizbowy parlament - Zgromadzenie Narodowe, które powołuje prezydenta, premiera, przewodniczącego Sądu Najwyższego i prezesa Najwyższej Izby Kontroli. System prawny Wietnamu oparty jest na konstytucji. Jednakże trzeba sobie zdawać sprawę $\mathrm{z}$ tego, iż została ona uchwalona dopiero w 1945r. Według opinii prof. Bui Dung Hieu przy pracach nad konstytucją z 1945r. i systemem prawnym Wietnamu korzystano $\mathrm{z}$ rozwiązań prawa $\mathrm{m}$. in. japońskiego i niemieckiego, lecz wzorowano się na 


\section{Comparative Legilinguistics 17/2014}

rozwiązaniach radzieckich z uwzględnieniem regulacji opartych na tradycji feudalnej. W latach po 1986 wprowadzono istotne zmiany dostosowujące prawo do przemian społecznych $\mathrm{w}$ bloku socjalistycznym pod hasłem đổi mói czyli „odnowa”, „pierestrojka”. Nastąpiło urynkowienie gospodarki. Prawa rynku nie dotyczą obrotu ziemią. Ziemia jest właśnością Narodu i w jego imieniu Państwo wydzierżawia ziemię na określony czas (praktycznie do 70 lat) i po upływie tego okresu trzeba starać się o ponowne uzyskanie prawa użytkowania gruntu. Obecnie stosunki prawne między obywatelami reguluje Kodeks Cywilny i Kodeks Handlowy w wersji wprowadzonej w życie w roku 2006.

Polska rzeczywistość prawna różni się znacząco od wietnamskiej. Przede wszystkim prawo polskie należy do rodziny tzw. prawa kontynentalnego i jest oparte na prawie rzymskim. Wiele instytucji funkcjonujących obecnie ma swoje korzenie właśnie w prawie rzymskim, które zostało recypowane wraz z kodyfikacjami napoleońskimi. „Kodyfikacje wpłynęły na kontynencie na rozwój specyficznego podziału dziedzin prawa, który wywodził się z pojęć prawa rzymskiego. W ślad za rozróżnieniem zgodnie z prawem rzymskim - prawa publicznego od prywatnego wyodrębniły się wyraźnie takie dziedziny prawa, jak prawo cywilne, państwowe, administracyjne, karne, procesowe itp.” (Sczaniecki 1985, 523)

\section{Metoda badawcza}

Przy dokonywaniu analizy i przekładu umów wietnamskich na język polski oparto się na metodzie porównania tekstów paralelnych, modelu pragmatycznym przekładu prawniczego zaproponowanym przez Kierzkowską (2002) oraz teorii skoposu Vermeera (2001). Przy przekładzie terminologii bezekwiwalentowej lub częściowo bezekwiwalentowej uwzględniono techniki zapewniania ekwiwalentów szeroko opisywane w literaturze przedmiotu (Kierzkowska 2002, Matulewska 2007 i 2013, Kubacki 2012). W celu potwierdzenia słuszności stosowanych metod zapewniania ekwiwalentów dla terminów wietnamskich posłużono się aktami prawnymi wietnamskimi zawierajacymi definicje ustawowe niektórych pojęć prawnych, słownikiem języka wietnamskiego Từ điển tiếng Việt pod redakcją Hoàng Phê z 2010r. i Đại từ điển Việt-Nga mới pod redakcją V.A.Andreeva i Nguyễn Tuyết Minh z 2012r. oraz akademickimi podręcznikami dla prawników dotyczącymi prawa zobowiązań umownych, stosowanymi w Wietnamie. Wynik analizy przedstawiono w postaci zestawienia integralnych elementów komparycji, oraz stosowanej w niej frazeologii i terminologii.

Teksty paralelne są w niniejszym artykule rozumiane jako teksty tego samego typu, na ten sam temat, które powstały w takiej samej sytuacji komunikacyjnej, jednakże wytworzone przez użytkowników różnych języków w oparciu o nieidentyczne warunki. Stanowią one bazę danych, którą posiłkuje się tłumacz traktując ją jako wzorce tekstowe pod względem języka, stylu i konwencji. Mając do dyspozycji tekst paralelny $z$ danej dziedziny prawa możemy być pewni, że zawarta w nim terminologia i frazeologia odnosi się do innej kultury, innego systemu prawnego, lecz do tej samej dziedziny prawa.

Parallel texts are texts produced by users of different languages under nearidentical communicative conditions. [...] Parallel text files [...] are part and parcel 
Bogdan Nowicki, Komparycja umów wietnamskich w przekładzie na język polski

of the material and mental equipment of the competent translator. This equipment is a vast database storing enormous experience. It is the key to an extensive knowledge of how texts are structured in the (text) world of different (communicative) cultures (Neubert 1996, 101).

Użytecznośc tekstów paralelnych $\mathrm{w}$ przekładzie została między innymi opisana w pracach Neuberta (1996), Fabricius-Hansen (2007), a w przekładzie prawniczym w pracach Šarčević (2000), Kubackiego (2013), Kaczmarek i Matulewskiej (2010).

\title{
Komparycja umów wietnamskich i jej struktura
}

Komparycja jest wstępną częścią dokumentu prawniczego. Obejmuje nagłówek i techniczne rozpoczęcie tekstu, jego wprowadzenie, określające rodzaj czynności, czas sporządzenia dokumentu, okoliczności oraz strony czynności. Część ta w umowach wietnamskich wykazuje istotne rozbieżności $\mathrm{w}$ porówaniu $\mathrm{z}$ paralelnymi tekstami umów formułowanych $\mathrm{w}$ języku polskim.

Komparycja w umowie wietnamskiej jest mocno sformalizowana. Jej struktura może być przedstawiona przy pomocy nastepującego schematu:

(i) inwokacja,

(ii) nazwa umowy i jej numer,

(iii) podstawy prawne,

(iv) miejsce i data zawarcia umowy,

(v) oznaczenie stron,

(vi) sentencja potwierdzająca wolę zawarcia przez obie strony umowy na wymienionych niżej warunkach.

Przykład 1. Komparycja umowy sprzedaży urządzeń i jej elementy składowe

Inwokacja:

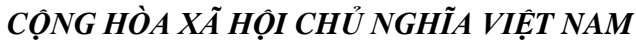 \\ Độc lập - Tụ do - Hạnh phúc \\ [SOCJALISTYCZNA REPUBLIKA WIETNAMU \\ NIEPODLEGŁA - WOLNA - SZCZĘŚLIWA]
}

Nagłówek wraz z numerem umowy:

HỌ'P ĐỔNG KINH TẾ [Umowa gospodarcza] (Số:...../2011/HĐKT)

$$
[N r: \ldots . . / 2011 / H Đ K T]
$$

Przedmiot umowy:

V/v: Mua bán máy móc thiết bị [w sprawie: handlu maszynami i urządzeniami]

Podstawa prawna: 
Căn cư vào bộ luật dân sụ số 33/2005/QH11 đã được Quốc hội nuớc Cộng hòa xã họi chủ nghĩa Việt Nam khóa XI kỳ hop thú 7 thông qua ngày 14/6/2005. Có hiệu lực thi hành tù ngày 01/01/2006.

[Opierając sie na Kodeksie Cywilnym nr 33/2005/QH11 zatwierdzonym przez Zgromadzenie Narodowe SRW na 7 posiedzeniu XI sesji w dniu 14-06-2005.

Wejście w życie z dniem 01-01-2006 r.]

- Căn cú vào bộ luật thuoong mại 36/2005 của Quốc hội nước CHXHCN Việt Nam khóa XI kỳ họp thứ 7 thông qua ngày 14/6/2005, có hiệu lục thi hành tù ngày 01/01/2006.

[Opierając sie na Kodeksie Handlowym 36/2005 zatwierdzonym przez

Zgromadzenie Narodowe SRW 7 na posiedzeniu XI sesji w dniu 14-06-2005.

Wejście w życie z dniem 01-01-2006 r.]

Preambuła (przyczyny/uzasadnienie zawarcia umowy):

- Căn cú vào chức năng, nhiệm vu sản xuất kinh doanh, nhu cầu và khả năng của hai bên.

[Opierając się na funkcji, obowiązku produkcyjnej działalności gospodarczej, potrzebach i możliwościach obu stron]

Data zawarcia umowy:

Hôm nay, ngày ...tháng ... năm 2011 [Dziś, dnia miesiąca $2011 \mathrm{roku}]$

Miejsce zawarcia umowy:

Tại tru sở Công ty TNHH CO' KHÍ CHẾ TAO CÔNG CU SIÊU VIÊT

[W siedzibie Mechaniczne Wytwarzanie Narzędzi Precyzyjnych Wietnam

Sp. z o.o.]

số 269 Phan Bá Vành, TP. Thái Bình.

[ul. Phan Ba Vanh 269 miasta Thai Binh ]

Oznaczenie stron umowy:

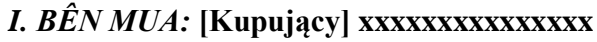

Đị chi : [Adres] xxxxxxxxxxxxxxxxx

Điện thoại : [Nr telef] Fax :

Mã số thuế : [Kod identyfikacji podatkowej NIP]

Tài khoản số : [Nr konta bankowego]

Tại : [w miejscowości]

Ngườ đại diện : [Przedstawiciel] - Chúc vu : [Stanowisko]

II BÊN BÁN : [Sprzedawca] C.TY TNHH CO' KHÍ CHÉ TAOO CÔNG CU

SIÊU VIÊT

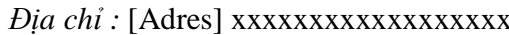

Điên thoai : Fax:

Mã số thuế : [Kod identyfikacji podatkowej NIP]

Tài khoản số : [Nr konta bankowego]

Người đại diện : [Przedstawiciel] Ông Nguyễn Văn Ba

Chức vu [Stanowisko] : Giám đốc [Dyrektor]

Sentencja potwierdzająca wolę zawarcia umowy przez obie strony na wymienionych niżej warunkach: 


\section{Inwokacja}

Đã cùng nhau bàn bạc, thỏa thuận và đi đến kí kết hợp đồng mua bán với các điều khoản nhu sau: [ Strony zawarły umowę sprzedaży o następującej treści:]

Wszystkie dokumenty oficjalne - zarówno pisane przez osoby prawne, jaki i osoby fizyczne, zawierają w nagłówku inwokację o następującej treści:

Przykład 2.

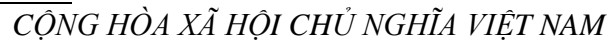

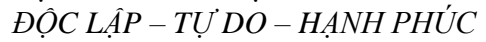

[SOCJALISTYCZNA REPUBLIKA WIETNAMU

NIEPODLEGŁA - WOLNA - SZCZĘŚLIWA]

Początek każdej umowy handlowej w języku wietnamskim zawiera więc napis o powyższej treści.

\section{Naglówek i dookreślenie przedmiotu umowy}

Pod napisem umieszcza się tytuł dokumentu - w przypadku umowy handlowej będą to słowa hơp đồng thuơng mại [umowa handlowa], hợ đồng mua bán [umowa sprzedaży] lub hợ đồng kinh tế [umowa gospodarcza] oraz numer porządkowy umowy. W języku wietnamskim umowa, porozumienie, kontrakt to hơp đồng, zaś handel to thuoong mai, umowa handlowa thumaczona jest jako hơp đồng thuoong mại. Spotykamy również tytuł umowy w postaci hợp đồng kinh tế, czyli [lit. umowa ekonomiczna / gospodarcza] lub hơp đồng kinh doanh [lit. umowa biznesowa/gspodarcza] rozumiana jako współpraca mająca na celu wspólne inwestowanie, lub prowadzenie działalności gospodarczej wspólnymi środkami. Do grupy tych umów należą między innymi umowy spedycyjne hợp đồng vận chuyển hàng hóa [lit. umowa przemieszczenia towarów], umowy przedstawicielstwa hơp đồng đại lý, czy umowy pośrednictwa handlowego hơp đồng môi giói thuoong mai W języku polskim używa się w powyższych przypadkach terminu umowa. Termin kontrakt należy do języka ekonomii, a nie języka prawa i w zasadzie nie występuje $\mathrm{w}$ tekstach umów, zwłaszcza tych sporządzanych przez prawników. $\mathrm{W}$ języku wietnamskim obok terminu hơp đồng, który thumaczymy jako umowa istnieje też pojęcie hiệp uoóc lub hiệp dịnh rozumiane jako porozumienie miedzynarodowe, o zabarwieniu politycznym i na język polski w zależności od typu i rangi dokumentu w jakim występuje thumaczone jest jako porozumienie, traktat lub umowa np. hiệp uó́c hòa bình [umowa pokojowa, traktat pokojowy], hiẹp uoóc riêng rẽ [porozumienie separatystyczne].

Za nazwą umowy w nagłówku umieszczany jest jej numer poprzedzony słowem $\boldsymbol{S} \hat{o}$ [Nr], łamany przez rok i skrót nazwy umowy. Nazwa i numer umowy przybiera wówczas postać:

\section{Przykład 3.}

HỢP ĐỔNG KINH TÉ Số:....../2011/HĐKT [Umowa gospodarcza $\mathrm{Nr}$..../UG]

Może się okazać, że nazwa umowy (w powyższym przykładzie: Umowa gospodarcza) musi byc doprezyzowana, wtedy pod nazwą i numerem pojawić się może zapis o treści np: 
Przykład 4.

V/v: Mua bán máy móc thiết bi

gdzie skrót v/v odczytamy jako về việc [w sprawie]

[w sprawie: handlu maszynami i urządzeniami]

\section{Podstawy prawne i preambuta}

W następnej kolejności po nagłówku wymienione są podstawy prawne tj. stosowne rozporządzenia organów wyższego szczebla i preambuła zawierająca przyczyny zawarcia umowy. W praktyce jako pierwsze wymienia się stosowne artykuły konstytucji, innych ustaw, rozporządzeń ministerstw, a także zarządzenie dyrektora instytucji lub bezpośrednich przełożonych stron przystępujących do zawarcia umowy. Zwyczaj wyszczególniania podstaw prawnych zawieranej umowy nie jest spotykany w umowach polskich, rosyjskich, niemieckich czy angielskich.

Wymienianie podstaw prawnych rozpoczyna się słowem căn cú, które na język polski można przetłumaczyć jako rzeczownik [podstawa, punkt oporu, baza] lub czasownik [opierać się na czymś, bazować na czymś].

Zauważmy, że:

(i) po słowie căn cú może występować od razu nazwa aktu prawnego np.: căn cú [podstawa] Luật thuoong mại [prawo handlowe], co w thumaczeniu na język polski wymaga użycia partykuły 'na' lub 'o' i w konsekwencji uzyskujemy w tłumaczeniu na język polski: „w oparciu o prawo handlowe” bądź „opierając się na prawie handlowym", co jest identyczne z konstrukcją z następnego punktu.

\section{Przykład 5.}

Căn cư Luật thương mại 2005 [W oparciu o Kodeks Handlowy 2005]

(ii) może też występować konstrukcja căn cú vào Luật thưong mại, gdzie słowo vào thumaczymy jako [w, do, na]. Przy tłumaczeniu na język polski użyjemy znaczenia vào [na] i mamy do wyboru konstrukcje: „opierając się na Prawie Handlowym”, „na bazie Prawa Handlowego”, „na podstawie Prawa Handlowego". może wystąpić konstrukcja căn cú theo, gdzie sowo theo znaczy [według, w ślad za, następować]. W tej sytuacji przetłumaczymy tę konstrukcję jako „w oparciu o..."

$\underline{\text { Przykład } 6 .}$

Căn cứ theo giấy ủy quyền số [w oparciu o pełnomocnictwo nr...]

Uzasadnienie zawarcia umowy może mieć różne formy np.

\section{Przykład 7.}

Căn cú vào đon chào hàng

[W oparciu o ofertę] 


\section{Przykład 8.}

Căn cú vào nhu cầu và khả năng thục hiện của hai đơn vị.

[Mając na względzie potrzeby obu jednostek i możliwości ich urzeczywistnienia]

Przykład 9.

- Xét theo nhu cầu và năng lục của các bên.

[Rozpatrując potrzeby i kompetencje stron]

\section{Przykład 10.}

-Căn cứ vào chức năng, nhiệm vu sản xuất kinh doanh, nhu cầu và khả năng của hai bên.

[Opierają się na funkcji, obowiązku produkcyjnej działalności gospodarczej, potrzebach i możliwościach obu stron]

Po wymienieniu podstaw prawnych i przyczyn zawarcia umowy umieszcza się formułkę zawierającą datę:

\section{Przykład 11.}

Hôm nay, ngày xx tháng yy năm zzzz chúng tôi gồm có:

[dzisiaj, dnia xx miesiąca yy roku zzzz my w osobach:]

\section{Miejsce i data zawarcia umowy}

Miejsce i datę zawarcia umowy można też przedstawić przy użyciu następującego schematu:

\section{Przykład 12.}

Hôm nay ngày dzień tháng miesiạc năm rok tại miejscowość i ulica chúng tôi gồm (có):

[Dzisiaj, dnia dzień miesiąca miesiąc roku rok w miejscowość i ulica my w osobach: ...]

Należy zwrócić uwagę na to, że po słowie tại [w] prócz nazwy miejscowości i adresu może być wymieniona nazwa przedsiębiorstwa.

\section{Oznaczenie stron umowy}

Po dacie następuje pełne przedstawienie stron umowy, wraz z adresami, nazwiskami oraz stanowiskami zajmowanymi przez osoby wyznaczone do zawarcia umowy, oraz innymi istotnymi danymi jak na przykład numerami identyfikacji podatkowej. W tym miejscu umowy są również podawane numery upoważnień do podpisania umowy, jeżeli są konieczne. Przedstawienie stron wykonuje się w postaci tabelki oddzielnie dla każdej ze stron. Strony oznaczane są literami A i B, lub podaniem funkcji strony w umowie, lub występują obydwa oznaczenia jednocześnie: Np.

\section{Przykład 13.}

Strona A: Strona kupująca NAZWA FIRMY

Strona A: NAZWA FIRMY

Strona kupująca: NAZWA FIRMY 


\section{Comparative Legilinguistics 17/2014}

W tym ostatnim przypadku, zwłaszcza gdy nazwa strony składa się z kilku wyrazów (np. bên chủ phuoong tiện giao thông) za nazwą strony podaje się informacje o skrótowym nazywaniu strony w dalszej części umowy. Możliwe są tu dwa często spotykane sformułowania:

\section{Przykład 14.}

gọi tắt là bên $A$ [nazywana w skrócie stroną $\mathrm{A}$ ]

sau đây gọi là bên $A$ [zwana w dalszej części umowy stroną $\mathrm{A}$ ]

Tabela 1. Oznaczenia stron umowy

\section{Bên $A$ [Strona A ]}

Tên doanh nghiêp: [Nazwa przedsiębiorstwa]

Đị chi tru sỏ chính: [Adres głównej siedziby].

Điện thoại: [Nr telefonu] Fax:

Tài khoản số: [Numer konta bankowego]

Mở tại ngân hàng: [Nazwa banku]

Đại diện là: [Przedstawiciel]

Chúc vu: [Stanowisko].

Giấy ủy quyền $[$ Pełnomocnictwo $]$ số: $[\mathrm{Nr}] \ldots$ ngày $[\mathrm{z}$ dnia $]$.... tháng $[$ miesiąc $]$.... năm [rok]

Do $[$ przez $]$.................. chức vu [stanowisko] $k y ́$ [podpisane].

Dla drugiej ze stron należy podać dane w takim samym formacie. Zmianie ulegnie oczywiście pierwszy wers i przyjmie postać:

\section{Przykład 15.}

\section{Bên $B$ [Strona B]}

W praktyce niektóre z punktów, wymienionych w ogólnym schemacie przedstawionym powyżej $\mathrm{w}$ tabeli 1, mogą $\mathrm{w}$ konkretnej umowie być pominięte. W zależności od rodzaju umowy strony mogą być określane funkcją jaką pełnią w danej umowie.

Przykład 16.

bên mua - bên bán

[kupujący - sprzedawca]

\section{Przykład 17.}

bên gưi tài sản - bên giũ tài sản

[strona dostarczająca towar - strona przechowująca towar]

\section{Przykład 18.}

bên chủ hàng - bên chủ phuoong tiện giao thông

[właściciel towaru - właściciel środka transportu]

\section{Przykład 19.}

bên thuê dịch vu - bên (cung cấp) dịch vu

[usługodawca - usługobiorca] 


\section{Przykład 20.}

bên môi giới - bên được môi giới

[pośrednik - korzystający z pośrednictwa]

\section{Przykład 21.}

ben thuê - bên cho thuê

[wydzierżawiający - dzierżawca]

\section{Przykład 22.}

bên chủ đầu tu - bên tổ chức nhận thầu xây dựng

[strona inwestora - strona biorąca udział w przetargu]

\section{Zapisywanie imienia i nazwiska wietnamskiego}

Zapisywanie imienia i nazwiska sprawia spore trudności, zwłaszcza przy wypełnianiu druków z rubrykami „nazwisko” i „imiona”. Problem w tym, że „imię i nazwisko” wietnamskie jest 3 członowe i prócz imienia i nazwiska w sensie europejskim zawiera jeszcze łącznik đệm. W odróżnieniu do języka polskiego, niemieckiego i rosyjskiego w języku wietnamskim jako pierwsze zapisywane jest nazwisko. Jest ono jednosylabowe i liczba możliwych nazwisk jest bardzo skąpa w porównaniu do nazwisk polskich. Nazwisko świadczy o przynależności do rodu feudalnego lub dynastii. Około 1/3 populacji nosi nazwisko Nguyễn - ostatniej rządzącej dynastii.

Imię zapisywane jest jako trzeci człon „imienia i nazwiska”. Różnorodność imion jest olbrzymia i zależy tylko od wyobraźni rodziców, a w zasadzie ojca dziecka. Imiona żeńskie to nazwy np. owoców (popularne na wsi), kwiatów, pozytywnych cech charakteru. Imiona męskie to często cechy charakteru mężczyzny takich jak odwaga, talent. Imieniem może być liczebnik wskazujący numer kolejny dziecka np. popularne imię żeńskie lub męskie $B a$ [trzy]. Pomiędzy imieniem a nazwiskiem znajduje się jednosylabowy łącznik. Nadawany jest przez rodziców, lecz pełni funkcje oznaczania przynależności do rodziny w szerszym znaczeniu. Historycznie pełnił również funkcję określenia płci - kobiety otrzymywały i do dziś w tradycyjnych rodzinach, zwłaszcza na wsi nadal otrzymują łącznik „Thị”.

Wśród nowych tendencji nadawania imion można zauważyć trzy:

i) rezygnację z lącznika tzn. nadawanie imion na wzór europejski,

ii) nadawanie imion będących słowami dwusylabowymi tzn. forma pozostaje wietnamska, lecz treść - europejska,

iii) nadawanie imion dwusylabowych z pozostawieniem łącznika.

\section{Adresy stron}

Adres podaje się w formacie „słowo số [numer]” numer domu, nazwa ulicy, nazwa dzielnicy, nazwa miasta. Niekiedy przed nazwą dzielnicy można spotkać słowo Quận [dzielnica]. Podany wyżej sposób dotyczy sytuacji, gdy adresat znajduje się przy głównej ulicy miasta. Konstrukcja miasta wietnamskiego jest inna od europejskiej i polega na tworzeniu sieci bezprzelotowych zaułków. Zaułki nie mają nazwy, adresowane są podaniem numeru ulicy głównej, gdzie zaułek się zaczyna. Wejście w zaułek $n g o \tilde{~ t o ~ s z c z e l i n a ~ o ~ s z e r o k o s ́ c i ~ p o n i z ̇ e j ~} 3 \mathrm{~m}$., więc samochód osobowy może tam wjechać. Zaułek taki po kilkudziesięciu metrach się rozwidla tworząc sieć coraz to 126 


\section{Comparative Legilinguistics 17/2014}

węższych zaułków ngách. W takim wąskim zaułku również może się znajdować siedziba firmy. Adresowanie w takim przypadku to podanie numeru ulicy głównej, gdzie zaczyna sie zaułek ngõ, podanie numeru przy zaułku ngõ, gdzie zaczyna się zaułek ngách i podanie numeru domu adresata np. nhà số 25 [dom nr 25]. Pełny hipotetyczny adres może wyglądać następujaco: Công ty $\mathrm{ABC}$ nhà số 25 ngách 31 ngõ 108 phố Lo Đúc, quận Hai Ba Trưng, Hà Nội.

Po wyszczególnieniu danych adresowych stron umowy następuje klauzula potwierdzająca wolę zawarcia umowy, która może mieć następujacą postać:

\section{Przykład 23.}

Đã cùng nhau bàn bạc, thỏa thuận và đi đến ki kết hợp đồng mua bán với các điều khoản nhu sau:

[Strony zawarły umowę sprzedaży o następującej treści:]

\section{Przykład 24.}

Sau khi bàn bạc thống nhất hai bên nhất trí ký hợp đồng về mua bán thuốc năm 2012 với các điều khoản chính nhu sau:

[Po uwzględnieniu argumentów stron, strony jednomyślnie zawarły umowę sprzedaży w roku 2012, o następującej treści]

\section{Przykład 25.}

Hai bên thống nhất ký kết Hợp đồng này với các điều khoản và điều kiện duới đây. Các bên cam kết có đầy đủ năng lục thực hiện tất cả các nghĩa vu trong Hợp đồng và không nhận thấy bất kỳ trở ngại liên quan đến việc thục hiện Hợp đồng.

[Strony uzgodniły następujące warunki umowy: Strony potwierdzają posiadanie pełnych kompetencji do realizacji wszystkich obowiązków (wynikających) $\mathrm{z}$ umowy i nie widzą jakichkolwiek przeszkód związanych z realizacją Umowy.]

\section{Przykład 26.}

Sau khi đã bàn bạc thoả thuận ký kết hợp đồng với các điều khoản sau:

[Po uwzględnieniu argumentów stron, zawarto umowę o następującej treści:]

\section{Przykład 27.}

Hai bên thống nhất thỏa thuận nội dung hợp đồng nhur sau:

[Obie strony uzgodniły poniższą treść umowy]

\section{Wnioski translacyjne wynikające z porównania tekstów paralelnych}

Z uwagi na inną kolejność przedstawienia informacji i inne połączenie nagłówka z oznaczeniem stron thumacząc początek umowy trzeba rozstrzygnąć czy chcemy uzyskać tłumaczenie bliskie oryginałowi, czy thumaczenie bliskie odbiorcy. W zależności od tego wybieramy w pierwszej kolejności budowę schematyczną początku umowy wietnamskiej, lub umowy polskiej. Schemat nagłówka umowy w języku wietnamskim oraz polskim zestawiono w poniższej tabeli. 
Bogdan Nowicki, Komparycja umów wietnamskich w przekładzie na język polski

Tabela 2.

\begin{tabular}{|c|c|}
\hline umowa wietnamska & umowa polska \\
\hline 1. Inwokacja & 1. .................brak ...... \\
\hline 2. Nazwa umowy i jej numer & 2. Nazwa umowy (numer \\
\hline 3. Podstawy prawne & nieobowiązkowy) \\
\hline 4. Miejsce $\mathrm{i}$ data zawarcia umowy & 3. ...............brak ... \\
\hline 5. Oznaczenie stron & 4. Miejsce i data zawarcia umowy \\
\hline 6. Sentencja potwierdzająca wolę & 5. Oznaczenie stron \\
\hline $\begin{array}{l}\text { zawarcia przez obie strony umowy } \\
\text { na wymienionych niżej } \\
\text { warunkach. }\end{array}$ & 6. Gramatyczne powiązanie z klauzulami \\
\hline
\end{tabular}

Podstawową różnica gramatyczną jest zastosowanie w umowach polskich strony biernej, zaś umowy wietnamskie pisane są w oparciu o strone czynną, co po przyjęciu stosownego schematu trzeba wziąć pod uwagę podczas tłumaczenia. Tłumaczenie nagłówka umowy polskiej według schematu polskiego na język wietnamski powinno mieć postać konstrukcji w stronie biernej jak w poniższym przykładzie:

Hơp đồng nazwa umowy được ký kết vào ngày data ơ miejscowość giũa bên $X$ và bên Y với nội dung nhu sau:

Tłumaczenie klauzuli oznaczenia stron, która jest związana $\mathrm{z}$ nagłówkiem umowy, zostało już omówione częściowo powyżej. Tłumaczenie umowy z języka wietnamskiego na język polski przy zachowaniu formy umowy polskiej rodzi określone problemy związane $\mathrm{z}$ deklinacją rzeczowników $\mathrm{W}$ języku polskim. Konstrukcja oznaczenia stron w języku wietnamskim, niezależnie od jej sformułowania w stronie biernej czy czynnej, nie wykazuje różnic fleksyjnych. W języku polskim zastosowanie strony biernej wymusza podanie nazw podmiotów umowy oraz ich danych adresowych w narzędniku.

Przykład 28.

\section{Umowa}

Zawarta w dniu ....... W Poznaniu

Pomiędzy Przedsiebiorstwem Wielobranżowym „AS” Sp.zo.o. a Bankiem

Spółdzielczym „Rolnik” (nazwy podmiotów w narzędniku)

Umowy wietnamskie formułowane są według schematu:

Strona A: Przedsiębiorstwo Wielobranżowe „AS” i

Strona B: Bank Spółdzielczy Rolnik

Zawarły w dniu.....w Poznaniu umowę o następującej treści.

(nazwy podmiotów w mianowniku)

Możliwe jest również tłumaczenie na język wietnamski bliższe polskiemu oryginałowi $\mathrm{z}$ zastosowaniem strony biernej w języku wietnamskim, i przyjmie ono wtedy postać:

Hợp đồng được 


\section{Comparative Legilinguistics 17/2014}

Bên A: Przedsiębiorstwo Wielobranżowe „AS” và

Bên B: Bank Spółdzielczy Rolnik

Hôm nay, ngày ...... ở Poznan kí kết.

(Przy zamianie strony czynnej na bierną nie występują różnice fleksyjne)

Należy zdawać sobie sprawę z faktu, że znalezienie brakującej terminologii w procesie translacji wymaga ciągłego porównywania systemów prawnych tekstu w języku źródłowym i tekstu w języku docelowym, jak również znajomości aktualnej literatury z zakresu prawa. „Równoważność” odwołuje się do takiej samej wartości pomiędzy źródłem a tekstem docelowym zaś ,adekwatność” dotyczy poszczególnych aspektów tekstu. We współczesnym świecie, mimo tendencji globalnego ujednolicania, zarówno tradycje prawne, jak i kultury z którch pochodzą teksty znacząco różnią się od siebie. Problemy translacyjne potęgowane są również przez niejednoznaczności terminów lub zwłaszcza w języku wietnamskim - przez ich wieloznaczność. Równoważność tekstów musi zatem obejmować równoważność kulturową, gdyż w jednym systemie używa się koncepcji zupełnie nieznanych, a nawet obcych dla innego systemu. Z lingwistycznego punktu widzenia, doskonałą translacją jest taka, która jej nie przypomina. Stosownie do prawnych tekstów, udana translacja powinna ukazać zawartość tekstu, a wszystko to przy zastosowaniu równoważnych syntaks, semantyki i pragmatyki. Co jest szczególnie istotne dla tekstów z dziedziny prawa.

\section{Bibliografia}

Delisle, Jean (et al., ed.), 1999. Translation Terminology. Amsterdam/Philadephia: John Benjamins Publishing Company.

Fabricius-Hansen, Cathrine, 2007. Paralleltext und Übersetzung in sprachwissenschaftlicher Sicht, W: Übersetzung, Translation, Traduction. Ein internationales Handbuch zur Übersetzungsforschung, red. H. Kittel et al., 322-329, Berlin/New York: de Gruyter.

Kaczmarek, Karolina, Matulewska,Aleksandra, 2010. Comparison of parallel texts of petitions in Polish-Hungarian and Polish-English translation, W: Across Languages and Cultures. Akadémiai Kiadó, Vol. 11, no. 1, June 2010, 67-81.

Kierzkowska, Danuta, 2002. Ttumaczenie prawnicze, Warszawa: Translegis.

Kubacki, Artur Dariusz, 2012. Ttumaczenie poświadczone. Status, ksztatcenie, warsztat i odpowiedzialność tlumacza przysięglego. Warszawa: Wolters Kluwer.

Kubacki, Artur Dariusz, 2013. Teksty paralelne jako narzędzie pomocnicze przy sporządzaniu thumaczeń specjalistycznych. W: Comparative Legilinguistics 20013/13, 137-148.

Matulewska, Aleksandra, 2013. Legilinguistic Translatology. A Parametric Approach to Legal Translation. Linguistic Insights vol. 171. Bern: Peter Lang.

Matulewska, Aleksandra, 2007. Lingua Legis in Translation. Frankfurt am Main: Peter Lang $\mathrm{GmbH}$.

Matulewska, Aleksandra, 2010. Teksty paralelne a ustalanie konotatów i denotatów na potrzeby przekładu polsko-angielskiego. W: Legilingwistyka porównawcza, Tom 3/2010, 57-69. Poznań: UAM. 
Bogdan Nowicki, Komparycja umów wietnamskich w przekładzie na język polski

Neubert, Albrecht, 1996. Textlinguistics of Translation: The Textual Approach to Translation. W: Translation Horizons Beyond the Boundaries of Translation Spectrum. Translation Perspectives IX, Marilyn Gaddis Rose (ed.), 87-105. Binghamton: Center for Research in Translation.

Šarčević, Susan, 2000. New Approach to Legal Translation. The Hague: Kluwer Law International.

Sczaniecki, Michał, 1985. Powszechna historia państwa i prawa. Warszawa: Państwowe Wydawnictwo Naukowe.

Smith, Sylvia A., 1995. Culture Clash: Anglo-American Case Law and German Civil Law in Translation. W: Translation and the Law, American Translators Association Scholarly Monograph Series, vol. VIII, Marshall, Morris (ed.), 181-197, Amsterdam/Philadelphia: John Benjamins Publishing Company.

Vermeer, Hans J., 2001. Skopos and Commission in Translational Action, W: The Translation Studies Reader, Venuti, Lawrence / Baker, Mona (eds.), 221-236. London/New York: Routlege. 